\title{
Research and Practice on Teaching Quality Assurance and Monitoring System Against the Background of Transformation of Local Applied Undergraduate Colleges and Universities
}

\author{
Guohua Wang ${ }^{1, *}$ Mupeng Diao ${ }^{1}$
}

\author{
${ }^{1}$ Heihe University, Heihe, Heilongjiang 164300, China \\ *Corresponding author. Email:wangguohua1970@163.com
}

\begin{abstract}
At present, there are still some practical problems in the structure and operation mechanism of the teaching quality monitoring system in applied undergraduate colleges and universities, and there is no consensus on the solutions. The author believes that to build a quality monitoring system for application-oriented talent training, it is necessary to establish the concept of integrating subject education and vocational education, and innovate the training model of applied talent. It is also necessary to establish a quality control concept for the whole process of talent training, and formulate teaching quality standards and build a monitoring system must be compatible with serving local economic development. The key link in the training and monitoring of application-oriented talents should be grasped, and the breadth and depth of the evaluation and analysis of teaching quality should be broadened. Exploring the teaching quality monitoring, regulation and feedback mechanism will be an effective guarantee for the continuous improvement of the quality of teaching and personnel training.
\end{abstract}

Keywords: quality monitoring, evaluation system, key links, monitoring mechanism

\section{INTRODUCTION}

The quality of teaching is the lifeline of the school's survival and development. Against the current background of the popularization of higher education, whether the training quality of applied technology talents in applied undergraduate colleges and universities can meet the needs of regional economic and social development has also attracted much attention, and constructing a standardized, scientific, efficient and practical teaching quality monitoring and guarantee system to achieve the purpose of improving the quality of talent training is a task that must be accelerated in the transformation and development of applied universities.

*Project: The 2018 Higher Education Teaching Reform Research Project "Research and Practice of Teaching Quality Assurance and Monitoring System in the Transformation of Local Applied Undergraduate Colleges and Universities" (No. SJGZ20180040).

\section{THE STATUS QUO AND EXISTING PROBLEMS OF TEACHING QUALITY MONITORING SYSTEM STRUCTURE AND OPERATION MECHANISM IN APPLIED UNDERGRADUATE COLLEGES AND UNIVERSITIES}

\section{A. Sticking to the traditional model, lacking innovation, and deviating from the philosophy of training applied talents in terms of educational concepts}

The basic structure of the teaching quality monitoring system of applied undergraduate colleges is roughly the same, which basically includes organizational guarantees, quality objectives, information collection, evaluation and analysis, information feedback and regulation, etc. The existing problems are as follows: the school-running goals are not clear enough, which is still called a "grey area"; the system construction is not yet perfect, especially the monitoring and guarantee of the practical links of applied undergraduate colleges and universities has not yet formed a complete chain; tracking feedback is not efficient enough, and there are phenomena that 
problems are not solved in time, problems are not solved, and problems are ignored.

\section{B. Insufficient effectiveness, imperfect organizational structure and feedback mechanism, and weak monitoring}

The internal teaching quality assurance system of colleges and universities is usually manifested in teaching quality management in higher education practice, which is reflected in the process check of the three nodes of the beginning, mid-term and end of the semester, promoting the evaluation methods of student evaluation, supervision and evaluation, or peer evaluation, and adopting relevant measures to discipline teachers who experience teaching accidents. The internal teaching quality assurance system of most local undergraduate colleges is often promoted by projects rather than problem research. In particular, a truly reasonable and rational assurance system has not been constructed. The construction of its quality assurance system is mainly promoted by the school and the educational affairs department, and the effect is not obvious at the grassroots level. Some faculty and staff have insufficient knowledge of quality management and passive behavior. Front-line teachers are more concerned about how to complete the "determined action" and avoid teaching accidents, resulting in poor teaching quality monitoring and a decline in actual teaching quality. A sound internal teaching quality guarantee should be coordinated by multiple departments, organizations at all levels, and full participation.

\section{There are defects in operating mechanism}

The teaching quality monitoring process is unbalanced. The current quality monitoring mainly focuses on classroom teaching, while the monitoring of other teaching links and teaching processes is less; there is more attention to theoretical teaching monitoring, but not enough to monitor practical teaching links; the teaching quality evaluation system is not perfect, and there is still a lack of scientific and reasonable teaching quality evaluation guidance. In the evaluation process, human factors still have more influence and it is difficult to be truly scientific and objective; the scope of teaching quality monitoring is still relatively narrow. The monitoring of teachers' teaching activities is strict, but the monitoring of students' learning is not effective enough. Students' knowledge examination is paid more attention to, and there is a lack of methods to assess students' quality and abilities.
D. Local undergraduate colleges and universities are generally unclear or even confused about the functions of the teaching evaluation organization, and have insufficient understanding of the task of teaching evaluation

Judging from the actual situation of most newlybuilt local undergraduate colleges and universities, the main work of school-level supervision is limited to indepth classroom listening, and it has failed to give full play to its guiding and decision-making role in teaching quality monitoring. In most local undergraduate colleges and universities, the quality control and management department only serves as a department, attached to the Academic Affairs Office and other related institutions. Even if the teaching quality department is set up or the education and teaching evaluation institutions are set up separately, their functions are limited to the supervision of administrative affairs within the teaching management department. The teaching management committees and academic committees set up by local undergraduate colleges and universities usually only provide relevant suggestions when the school's teaching quality standards and measures are formulated, without arranging their corresponding substantive powers.

\section{THE CONSTRUCTION OF INTERNAL TEACHING QUALITY ASSURANCE SYSTEM IN LOCAL UNDERGRADUATE COLLEGES}

\section{A. Establishing the concept of integrating subject education and vocational education, and innovating application-oriented talent training models}

In the process of implementing the strategic transformation of innovative talent training models in applied undergraduate colleges, the key to reform is to build an education and teaching system that connects universities and professions, so that the university's curriculum system, teaching content and training process are oriented to the world of work and life through the transition of subject knowledge to professional knowledge and practical knowledge, so as to realize the combination of knowledge and ability, theory and practice. In this way, applied undergraduate colleges can truly become a place for "useful learning", and applied talent training can truly be implemented.

\section{B. Establishing a quality control concept for the whole process of talent training so that the quality standards and the monitoring system are in the same line}

The teaching quality assurance system refers to an integrated teaching working mechanism and operating system that take teaching quality assurance based on material teaching resources and high-quality teachers as the basis, to follow the law, give priority to teaching, 
and serve students as the purpose of guaranteeing teaching quality, and to monitor, evaluate, feedback and correct as the means of teaching quality, while influencing and interacting with each other.

Applied undergraduate colleges and universities should establish a quality control concept for the whole process of talent training, regard quality control as the embodiment and guarantee of the status of the teaching center to make it run through the whole process of talent training and cover talent training goal formulation, teaching resource management, teaching process management and talent training performance evaluation, and establish a set of quality control points that unify quality evaluation standards and quality monitoring.

\section{Constructing a comprehensive quality management operating mechanism on the operating mechanism}

The construction of the teaching quality guarantee system of local undergraduate colleges requires the theory and methods of total quality management as the theoretical basis for constructing the teaching quality assurance system, so that the constructed teaching quality assurance system fully reflects the basic characteristics of total quality management such as systemicity, comprehensiveness, and dynamics. It is necessary to make teaching quality assurance system cover the whole process of talent training, and establish and improve the teaching quality assurance operating mechanism of newly-built local undergraduate colleges. It is also necessary to strictly follow the expected goalplanning-implementation-inspection-feedback-

supervision procedures, and to implement quality management of educational activities in full elements(teaching environment, teachers, students, teaching content, teaching methods and means, the organization of teaching activities, examination and evaluation, etc.), the entire process (the entire process of teacher teaching, the entire process of student learning, the entire process of functional department management), and all-round ways (school departments, parent requirements, and social employer opinions). Local undergraduate colleges and universities should take the implementation of the "quality project" as an opportunity to urge the faculty and staff of the school to establish quality awareness, break the traditional fragmentation and the disadvantageous situation of fighting each other, and accumulate strength and wisdom from all aspects and form a joint force. They should also highlight the quality of teaching as the core of all tasks, eliminate all the factors that are not conducive to improving the quality of teaching, so that all tasks can always be carried out around the quality of teaching, creating a harmonious and progressive school active development working atmosphere, and forming a good situation of full participation, full monitoring and comprehensive improvement of teaching quality assurance.

\section{Prioritizing the development of key control points in operation mode}

The issue of education quality assurance, from an internal point of view, is to establish a mechanism to promote the continuous improvement and improvement of the quality of education and teaching in colleges and universities. Through the analysis of the quality generation process, it is important to find the key control points of the quality of education and teaching, and implement the control by using systems, procedures, norms, and culture to achieve the goals of quality management. For the newly-built local undergraduate colleges, although the teaching quality assurance system has been initially established, the soundness and improvement of many aspects of the system requires a large amount of funding. In the face of the limited funding income of newly-built undergraduate colleges, it is unrealistic to comprehensively improve the relevant factors affecting teaching quality. It can only integrate limited teaching resources and teaching funds and form a joint force, and give priority to the development of the key points of the undergraduate teaching quality generation process and quality control. Through the development of key points such as the development of teachers and courses with priority, step by step, and stage by stage, it is also necessary to effectively promote the improvement of the level of the teaching staff and the quality of curriculum construction. At the same time, it is a necessity to sort out the existing teaching quality management methods, find teaching quality management loopholes, innovate the teaching quality management incentive mechanism, step by step, and gradually develop and improve the teaching quality guarantee system.

\section{E. Improving management execution and teaching quality management in operation management}

The executive ability of management of higher education institutions is the "core link" between the teaching quality goal and the talent training result, and it is also the decisive factor in whether the management goal can be achieved. The main body ultimately settles in each grassroots unit of administration and teaching management and individual teachers. To build a new local undergraduate college to improve management execution, the first is to establish a people-oriented concept. Therefore, it is fully consider the needs of teachers as a core group, establish a relaxed and harmonious career environment, fully consider the teaching needs and desires of each teacher, and truly organically integrate the realization of teachers' personal values with the development of the school, and stimulate teachers' teaching passion and work initiative 
for improving quality. The second is to improve the quality management mechanism, focusing on establishing the service commitment system of the school administration department, the teaching quality management evaluation system of the teaching unit and the teacher teaching quality incentive mechanism, and fully stimulate the vitality of administrative departments, grassroots teaching units, and teachers and students, so as to form a lasting motivation mechanism that activates the enthusiasm of managers and teachers to create and work.

\section{F. Constructing incentive and restraint mechanisms on operational effects to ensure operational effectiveness}

Quality work is not a "one-shot deal". It requires long-term unremitting efforts and practice from all faculty members, from leadership to ordinary teachers. However, quality work is often neglected due to the influence of many factors, having a short-term nature. If people want to change this passive situation and change from being passive in dealing with inspections to actively improving the quality of teaching, it is very important to establish corresponding incentive and restraint mechanisms. Incentive guidance and monitoring methods have always been opposed and unified. On the surface, the two are opposed to each other in connotation and mechanism, but they are highly unified in essence and goals, and both take the promotion of school teaching quality as the fundamental goal. It has an important guiding role in fully mobilizing the enthusiasm and creativity of the teachers and students of the school, and improving the quality and efficiency of management.

\section{G. Strengthening the supervision of social personnel}

The supervision of social personnel should also become a focus in the construction of the external quality assurance system of higher education. Today, China's higher education management system has undergone major changes. The previous governmentmanaged management model has been gradually broken. Colleges and universities have begun to face the society, run their own schools, and become independent legal entities and school-running entities. Social workers are also increasingly participating in higher education activities and taking part of the responsibilities of higher education, such as parents of students, enterprises, industrialists, and so on. Therefore, it is necessary to attach importance to and give play to the role of social personnel in higher education quality assurance, so that social personnel have the right to participate in higher education quality monitoring. Unifying rights and responsibilities and forming a modern island of government regulation, social regulation, and university self-management have become an urgent need for new local undergraduate colleges to reform the education quality assurance system.

\section{CONCLUSION}

In short, local undergraduate colleges and universities should learn from experience and lessons, and set up a corresponding undergraduate teaching quality assurance system based on their own new, local, and undergraduate characteristics. While doing a good job of evaluation, they should make better use of the opportunity of evaluation to find out the selfpositioning and realize the development of dislocation competition. Based on the place where the contribution is made, facing and serving local industries, it is also necessary for them to improve the quality of running schools, realize connotative development, ensure that local undergraduate colleges and universities can be in a more favorable position at the beginning of development, and form the right direction for sustainable development.

\section{References}

[1] Wang Jianhua. A Study on the Higher Education Quality: A Perspective of Management [J]. Journal of Higher Education, 2009 (2), p1-9. (in Chinese)

[2] Li Mingzhi. On the Reconstruction of Teaching Quality Assurance System in Colleges and Universities from the Perspective of Audit and Evaluation [J]. Beijing Education: Higher Education, 2015, 07-08: 103-105. (in Chinese)

[3] Li Ting. A Construction Study of Teaching Basic Status Data Collection on Newly Established Universities' Teaching Quality Monitoring System [J]. Journal of Qi Lu Normal University, 2015 (2): 7-11. (in Chinese)

[4] Li Guoqiang. Study on the Effects, Problems and Expectations of Internal Quality Assurance System in Colleges and Universities [J]. China Higher Education Research, 2016 (2): 111. (in Chinese)

[5] Fu Juan, Chen Tingzhu. Focus Issues and New Trends of Higher Education Quality Assurance - A Summary of "2015 Cross-Strait Higher Education Theory" [J]. Journal of Higher Education, 2016 (1): 106-109. (in Chinese)

[6] Chen Wenzhe, Liu Yun, Sun Guozheng. Construction of Quality Assurance System for Local Undergraduate Universities in Transition: Exemplified by Xiamen University of Technology [J]. Journal of Fujian University of Technology, 2015 (4): 182 186. (in Chinese) 